\title{
Pectolinarigenin - A Flavonoid Compound from Cirsium Japonicum with Potential Anti-proliferation Activity in MCF- 7 Breast Cancer Cell
}

\author{
Mingqian Lu ${ }^{1,2,3}$, Qingzhi Kong ${ }^{1,4 \star}$, Xinhua $\mathrm{Xu}^{2,3}$, Hongda $\mathrm{Lu}^{4}$, Zhongxin $\mathrm{Lu}^{4}$, Wei \\ $\mathrm{Yu}^{2,3}$, Bin $\mathrm{Zuo}^{2,3}$, Jin $\mathrm{Su}^{2,3}$ and Rong Guo ${ }^{2,3}$ \\ ${ }^{1}$ Hubei University of Chinese Medicine, Wuhan 430061, Institute of Oncology, China Three Gorges University, ${ }^{3}$ Oncology \\ Department, Yichang Central Hospital, Yichang 443000, ${ }^{4}$ Wuhan Central Hospital \& Wuhan Institute of Oncology, Wuhan \\ 430061, China.
}

*For correspondence: Email: lumqyc@sina.cn; Tel: +86-0717-6486745; Fax: +86-0717-6486745

\begin{abstract}
Purpose: To isolate high purity pectolinarigenin from Cirsium japonicum and evaluates its antiproliferative potential and induction of apoptosis activity in MCF-7 breast cancer cell.

Methods: Pectolinarigenin was purified by the combination of silica gel and Sephadex $\mathrm{LH}-20$ column chromatography. The structure was identified by ${ }^{1} \mathrm{H}$-nuclear magnetic resonance (NMR), ${ }^{13} \mathrm{C}$-NMR and electrospray ionization tandem mass spectrometry (ESI-MS) analyses. The anti-proliferation activity of pectolinarigenin was also evaluated by methylthiazolyldiphenyl-tetrazolium bromide (MTT) and colony formation assays in MCF-7 breast cancer cell.

Results: Pectolinarigenin showed potent anti-proliferation activity by inducing apoptosis and downregulation of Bcl2 expression in MCF-7 breast cancer cell. Protein expression of Bcl2 was almost completely inhibited upon the treatment with $25 \mu \mathrm{M}$ pectolinarigenin.

Conclusion: A rapid method to isolate high purity pectolinarigenin from C. japonicum and as well as evaluate its anti-proliferative potential and induction of apoptosis in MCF-7 breast cancer cells is presented for the first time. Induction of apoptosis of MCF-7 is via downregulation of Bcl2 expression.
\end{abstract}

Keywords: Cirsium japonicum, Anti-proliferation activity, Pectolinarigenin, Breast cancer, Apoptosis.

Tropical Journal of Pharmaceutical Research is indexed by Science Citation Index (SciSearch), Scopus, International Pharmaceutical Abstract, Chemical Abstracts, Embase, Index Copernicus, EBSCO, African Index Medicus, JournalSeek, Journal Citation Reports/Science Edition, Directory of Open Access Journals (DOAJ), African Journal Online, Bioline International, Open-J-Gate and Pharmacy Abstracts

\section{INTRODUCTION}

Cirsium japonicum belongs to the family of Compositae and is widely used in traditional Chinese medicine (TCM) for the treatment of haemorrhage, hepatitis, hypertension and blood circulation [1]. Pharmacological studies show that the extract of $C$. japonicum and its major constituents possess anti-tumor [1, 2], antidiabetic [3], antioxidant [4], anti-inflammatory [4], and antifungal [5]. C. japonicum contains significant amounts of flavonoid compounds, the principal characteristic of the flavonoid compounds are pectolinarin and pectolinarigenin (Figure 1), which exhibited powerful anti-diabetic, hepatoprotective and anticancer activities in vitro $[3,6,7]$.<smiles>COc1ccc(-c2cc(=O)c3c(O)c(OC)c(O)cc3o2)cc1</smiles>

Figure 1: Chemical structure of pectolinarigenin (1) 
A previous study has shown that the methanol extract of $C$. japonicum inhibits MCF-7 cell growth at both proliferation and apoptosis levels [8]. However, the active components have not been isolated and identified. Bcl2 gene is an important regulator of apoptosis, which is an over-expression in many solid organ tumours including breast cancer [9]. Increasing evidence supports their modulated expression in breast cancer cells and in many cases, their relation to chemotherapy response, outcome, and overall prognosis, as well as their value are important potent therapeutic targets [10].

The aim of this study was to determine a quick method to isolate high purity pectolinarigenin from $C$. japonicum and assess the biological activity of pectolinarigenin in breast cancer.

\section{EXPERIMENTAL}

\section{Plant material and equipment}

The aerial parts of $C$. japonicum were purchased from the Chinese herbal medicine market in Zhang Shu (Jiang Xi, China) in July 2010 and authenticated by Qingzhi Kong of Hubei University of Chinese Medicine. A voucher specimen (2010-07) has been deposited in the Hubei University of Chinese Medicine. The ${ }^{1} \mathrm{H}$ and ${ }^{13} \mathrm{C}-\mathrm{NMR}$ spectra were recorded on a Bruker Avance-400 FT-NMR spectrometer, with TMS internal standard. ESI-MS were recorded on 3200 Q-trap ESI-MS spectrometer (ABI, American). Column chromatography was carried with silica gel (200-300 mesh) and Sephadex LH20 (Pharmacia Co.). All the organic solvents used were of analytical grade and purchased from Sinopharm Chemical Reagent Co., LtdS (Shanghai, China). Bcl2 and Bax were purchased from Santa Cruz Biotechnology, Inc. Caspase 3 was obtained from Cell Signaling Technology. $\beta$-actin and Anti-poly (ADP-ribose) polymerase (PARP) were obtained from Sigma Chemical Company (Sigma-Aldrich). The cell culture medium Dulbecco's Modified Eagle Medium (DMEM); high glucose, without sodium pyruvate) and fetal bovine serum (FBS) were purchased from Hyclone Company (Logan, UT, USA). Acrylamide-bis solution (30\%; 29:1) was bought from Bio-Radlaboratories (Hercules, CA, USA), Inc. Protein content was tested using a BCA kit (Thermo Scientific).

\section{Cell line and culture}

The human breast cancer cells line, MCF-7, was purchased from American Type Culture Collection. MCF-7 Cells were cultured in DMEM medium supplemented with $10 \%$ heat inactivated fetal bovine serum (FBS), 100 units/ml penicillin and $100 \mu \mathrm{g} / \mathrm{ml}$ streptomycin at $37^{\circ} \mathrm{C}$ in a humidified incubator with $5 \% \mathrm{CO}_{2}$ (all reagents from Invitrogen, Carlsbad, CA). The cells were maintained in log phase by seeding twice a week at a density of $1 \times 10^{5} / \mathrm{ml}$, and the experiments were performed 1 day after trypsinization.

\section{Extraction and isolation of pectolinarigenin}

The powdered air-dried aerial parts of $C$. japonicum $(1 \mathrm{~kg})$ were extracted three times with $6 \mathrm{~L} 80 \%$ ethanol $/ 10 \% \mathrm{HCl}(4: 1, \mathrm{v} / \mathrm{v})$ in a conical flask and refluxed at $80{ }^{\circ} \mathrm{C}$ for $2 \mathrm{~h}$. The solvent was evaporated in vacuum and then the concentrated extract was partitioned with chloroform. The chloroform fraction was successively purified on silica gel (200-300 mesh) with $\mathrm{CHCl}_{3}-\mathrm{MeOH}$ gradient and on Sephadex $\mathrm{LH}-20$ with $\mathrm{CHCl}_{3}-\mathrm{MeOH}(1: 1)$ to yield compound 1 (61 mg).

\section{Cell growth determination by MTT assay}

MTT assay measures the ability of viable cells to reduce yellow 3-(4,5-dimethylthiazol-2-yl)-2,5diphenyltetrazolium bromide to purple formazan by mitochondrial succinate dehydrogenase (SDH). Cells $\left(1 \times 10^{3}\right)$ were seeded onto a 96-well plate in triplicate with $1,5,10,25$ and $50 \mu \mathrm{M}$ pectolinarigenin for $24 \mathrm{~h}$, and then the cells were washed three times with fresh medium and cultured for an additional 7 days. The medium was removed, and the MCF-7 cells were then incubated in DMEM medium containing 0.5 $\mathrm{mg} / \mathrm{ml}$ MTT for an additional $3 \mathrm{~h}$. The medium was removed, and dimethyl sulfoxide (DMSO) was added to dissolve the formazan. Absorbance was read at $490 \mathrm{~nm}$ in an ELISA reader (Bio-Rad iMARK $^{\mathrm{TM}}$ Mcroplate Reader). The absorbance of cultures treated with $0.1 \%$ DMSO was regarded as $100 \%$ cell viability.

\section{Colony forming assay}

For colony expansion assay, MCF-7 cells were plated in 6-well plates at a density of 1000 cells/well and allowed to adhere overnight. The culture medium was replaced with media containing indicated concentrations of pectolinarigenin. After exposure for $24 \mathrm{~h}$, the cells were washed twice with phosphate buffered saline (PBS). Fresh medium was then added, and the cells cultured at $37{ }^{\circ} \mathrm{C}$ in humidified $5 \%$ $\mathrm{CO}_{2}$ atmosphere for 8 - 10 days. The cells were viewed regularly under the microscope for colony formation. At termination, the culture medium was decanted, the cells rinsed with PBS and stained with crystal violet $(0.5 \%$ in $95 \%$ ethanol) for 5 min after fixation with $10 \%$ formaldehyde for $5 \mathrm{~min}$. 


\section{Western blotting assay}

The cells were washed twice with cold PBS and harvested in $150 \mu \mathrm{l}$ of Lysis Buffer RIPA (150 $\mathrm{mM} \mathrm{NaCl} ; 50 \mathrm{mM}$ Tris pH 8; $0.1 \%$ SDS; $0.5 \%$ sodium deoxicolate; $1 \%$ Nonidet P40; $5 \mathrm{mM}$ EDTA, $1 \mathrm{mM}$ PMSF, $1 \mu \mathrm{g} / \mathrm{ml}$ leupeptin, $1 \mu \mathrm{g} / \mathrm{ml}$ aprotinin and $2 \mathrm{mM}$ DTT). The cell homogenates were centrifuged at $10,000 \mathrm{~g}$ for $20 \mathrm{~min}$ at $4^{\circ} \mathrm{C}$. The resulting supernatant was used as a cellular protein for Western blotting analysis. The protein content in the lysates was measured by BCA protein assay. Equal amounts of proteins were electrophoresed in SDS-PAGE and the proteins transferred to polyvinylidene difluoride (PVD) membranes. The detection was achieved using the immobilon western chemiluminescent HRP Substrate kit (Millipore). The primary antibodies used are: PARP (Santa Cruz Biotechnology, Inc.), Caspase 3 (Cell Signaling Technology), Bcl2 (Santa Cruz Biotechnology, Inc.), Bax (Santa Cruz Biotechnology, Inc.) and $\beta$-actin (Sigma-Aldrich).

\section{Statistical analysis}

Statistical analyses were performed with GraphPad Prism software. Values are expressed as mean \pm SEM. Pair-wise comparisons were performed using Student's t test (two-tailed). $P<$ 0.05 was set as significant different.

\section{RESULTS}

\section{NMR and ESI-MS spectral data}

Pectolinarigenin (1): yellow crystal (methanol), $\mathrm{C}_{17} \mathrm{H}_{14} \mathrm{O}_{6}$, UV (MeOH) $\lambda_{\max }: 336,273 \mathrm{~nm}$, ESIMS $m / z$ : $313.1[\mathrm{M}-\mathrm{H}]^{-}{ }^{1}{ }^{\prime} \mathrm{H}-\mathrm{NMR}(400 \mathrm{MHz}$, DMSO$\left.d_{6}, \delta, p p m, J / H z\right): 6.86(1 \mathrm{H}, \mathrm{s}, \mathrm{H}-3), 6.61(1 \mathrm{H}, \mathrm{s}$, $\mathrm{H}-8), 8.02\left(2 \mathrm{H}, \mathrm{d}, \mathrm{J}=8.8, \mathrm{H}-2^{\prime}, 6^{\prime}\right), 7.10(2 \mathrm{H}, \mathrm{d}$, $\left.\mathrm{J}=8.8, \mathrm{H}-3^{\prime}, 5^{\prime}\right), 12.97(1 \mathrm{H}, \mathrm{s}, \mathrm{OH}-5), 10.78(1 \mathrm{H}$, $\mathrm{s}, \mathrm{OH}-7), 3.94\left(3 \mathrm{H}, \mathrm{s}, 6-\mathrm{OCH}_{3}\right), 3.86\left(3 \mathrm{H}, \mathrm{s}, 4{ }^{\prime}-\right.$ $\left.\mathrm{OCH}_{3}\right) \cdot{ }^{13} \mathrm{C}-\mathrm{NMR}\left(100 \mathrm{MHz}\right.$, DMSO- $\left.d_{6}\right): 163.8$ (C-2), 103.5 (C-3), 182.6 (C-4), 153.2 (C-5), 131.8 (C-6), 157.8 (C-7), 94.7 (C-8), 152.9 (C-9), 104.6(C-10), 123.3 (C-1'), 128.7 (C-2', 6'), 114.9 $\left(\mathrm{C}^{\prime} \mathrm{3}^{\prime}, 5^{\prime}\right), 162.7\left(\mathrm{C}-4^{\prime}\right), 60.4\left(6-\mathrm{OCH}_{3}\right), 55.9\left(4^{\prime}-\right.$ $\left.\mathrm{OCH}_{3}\right)$. The NMR data were consistent with the literature [11].

\section{Effect of pectolinarigenin on MCF-7 cell growth}

Treatment with pectolinarigenin inhibited cell proliferation in MCF-7 (Figure 2). The inhibitory effect on MCF-7 treated with 1, 5, 10, 25 and 50 $\mu \mathrm{M}$ pectolinarigenin were $16,31,61,82$, and 89 , respectively, compared with controls. This result suggested that pectolinarigenin caused a sustained growth arrest of MCF-7 in dosedependent manner.

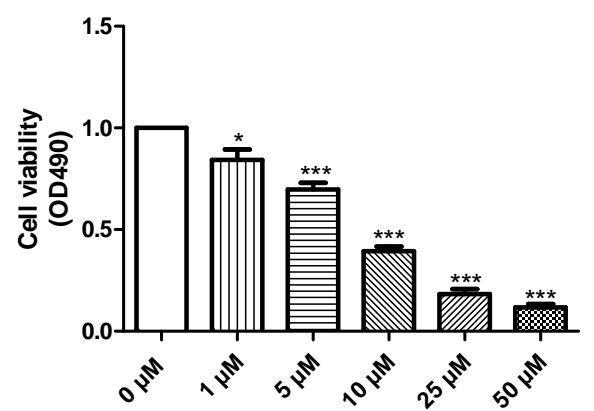

Figure 2: Inhibition of proliferation MCF-7 cells. MCF7 cells were exposed to different concentrations of pectolinarigenin. Data represent mean normalized optical densities \pm SEM $(\mathrm{n}=3) ;{ }^{*} p<0.05,{ }^{* * *} p<0.001$ compared control

\section{Colony formation}

To further investigate the inhibitory effect of pectolinarigenin on MCF-7 growth, colony formation assay was carried out. The results also revealed that pectolinarigenin elicited antiproliferation activity in MCF-7 in a dosedependent manner (Figure 3).

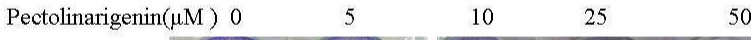

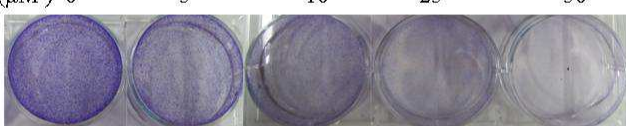 \\ Figure 3: Inhibition of colony formation in MCF-7 breast cancer cells by pectolinarigenin \\ Pectolinarigenin modulates apoptosis-related protein expression}

The results show that 5 and $25 \mu \mathrm{M}$ pectolinarigenin efficiently induced the cleavage of PARP and Caspapse 3 in MCF-7 cells after 24-h treatment (Figure 4). At the same time, a significant difference was found in the expression of $\mathrm{Bcl} 2$ and Bax. MCF-7 treated with 5 and 25 $\mu \mathrm{M}$ pectolinarigenin as it resulted in the downregulation of anti-apoptotic protein $\mathrm{Bcl} 2$ expression. However MCF-7 treated with $5 \mu \mathrm{M}$ pectolinarigenin, even upto $25 \mu \mathrm{M}$ pectolinarigenin there was no change $(p>0.05)$ in pro-apoptotic protein Bax expression (Figure $4)$.

\section{DISCUSSION}

Pectolinarigenin has been reported as an antitumor agent in mice with $\mathrm{S} 180$ and $\mathrm{H} 22$ tumor cells [1] and many other cancer cell lines, including lung cancer, colon cancer and renal cancer cells [2,7]. In the present study, we found that $5,10,25$ and $50 \mu \mathrm{M}$ pectolinarigenin significantly inhibit MCF-7 breast cancer cell 
proliferation. Pectolinarigenin, at a concentration of $50 \mu \mathrm{M}$, almost completely inhibited MCF-7 colony formation.

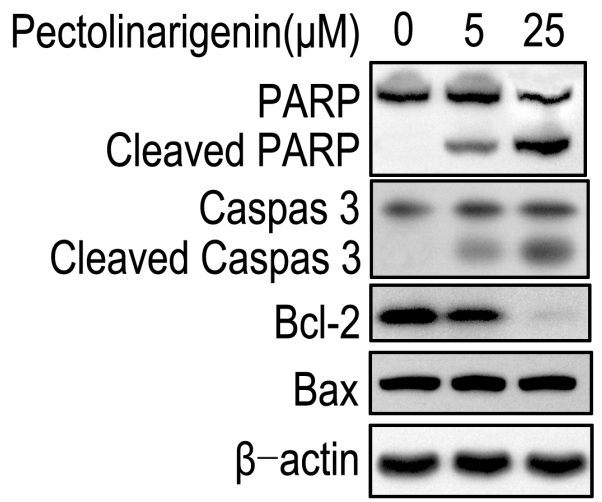

Figure 4: Modulation of apoptosis related protein expression in MCF-7 cells by pectolinarigenin.

Induction of apoptosis by pectolinarigenin is an important way to inhibit cancer cell growth. Caspase 3 is a member of the cysteine-aspartic acid protease family and a critical executioner of apoptosis [12]. PARP is a DNA repair enzyme, and cleavage of PARP facilitates cellular disassembly. Cleavage of Caspase 3 and PARP serves as markers of cell undergoing apoptosis [13]. Our findings indicate that 5 and $25 \mu \mathrm{M}$ pectolinarigenin induced cleavage of Caspase 3 and PARP and that pectolinarigenin inhibits MCF-7 cell proliferation via induction of MCF-7 apoptosis. The apoptosis-preventing effect of $\mathrm{Bcl} 2$ is counteracted by the pro-apoptotic protein, Bax; furthermore, the ratio of $\mathrm{Bax} / \mathrm{Bcl}-2$ mixture determines sensitivity to different apoptotic stimuli. While 5 and $25 \mu \mathrm{M}$ pectolinarigenin resulted in downregulation of $\mathrm{Bcl} 2$ protein expression, the isolate had no effect on Bax protein expression. Thus, downregulation of $\mathrm{Bcl} 2$ protein expression is the probable mechanism of induction of apoptosis by pectolinarigenin.

\section{CONCLUSION}

Induction of apoptosis of MCF-7 via downregulation of $\mathrm{Bcl} 2$ expression is the proable mechanism of action of pectolinarigen. Pectolinarigen inhibition of breast cancer cell MCF-7 proliferation not only an addition to the current knowledge of the compound's properties but also presents a novel potential therapeutic agent for the treatment of breast cancer.

\section{REFERENCES}

1. Liu S, Luo X, Li D, Zhang J, Qiu D, Liu W, She L, Yang $Z$. Tumor inhibition and improved immunity in mice treated with flavone from Cirsium japonicum DC. Int Immunopharmacol 2006; 6(9): 1387-1393.

2. Bonesi M, Tundis R, Deguin B, Loizzo MR, Menichini $F$, Tillequin $F$, Menichini $F$. In vitro biological evaluation of novel 7-O-dialkylaminoalkyl cytotoxic pectolinarigenin derivatives against a panel of human cancer cell lines. Bioorg Med Chem Lett 2008; 18 (20): 5431-5434.

3. Liao Z, Chen X, Wu M. Antidiabetic effect of flavones from Cirsium japonicum $D C$ in diabetic rats. Arch Pharm Res 2010; 33(3): 353-362.

4. Kim GH. Antioxidant and anti-inflammatory activities of ethanol extract from leaves of Cirsium japonicum. Food Sci Biotechnol 2008; 17(1): 38-45.

5. Yoon MY, Choi G, Choi Y, Jang K, Cha B, Kim JC. Antifungal activity of polyacetylenes isolated from Cirsium japonicum roots against various phytopathogenic fungi. Ind Crop Prod 2011; 34(1): 882-887.

6. Yoo YM, Nam JH, Kim MY, Choi J Park HJ. Pectolinarin and pectolinarigenin of Cirsium setidens prevent the hepatic injury in rats caused by $D$ galactosamine via an antioxidant mechanism. Biol Pharm Bull 2008; 31(4): 760-764.

7. Tundis $R$, Deguin B, Loizzo MR, Bonesi M, Statti GA, Tillequin F, Menichini F. Potential antitumor agents: Flavones and their derivatives from Linaria reflexa Desf. Bioorg Med Chem Lett 2005; 15(21): 47574760.

8. Kim D, Kang $S$, Ghil $S$. Cirsium japonicum extract induces apoptosis and anti-proliferation in the human breast cancer cell line MCF-7. Mol Med Rep 2010; 3 (3): 427-432.

9. Callagy GM, Pharoah $P D$, Pinder S E, Hsu FD, Nielsen TO, Ragaz J, Ellis IO, Huntsman D, Caldas C. BCl2 is a prognostic marker in breast cancer independently of the Nottingham Prognostic Index. Clin Cancer Res 2006; 12(8): 2468-2475.

10. Thomadaki H, Scorilas A. Molecular profile of the Bcl-2 family of the apoptosis related genes in breast cancer cells after treatment with cytotoxic/cytostatic drugs. Connect Tissue Res 2008; 49(3): 261-264.

11. Kim EY, Jho HK, Kim DI, Rhyu MR. Cirsium japonicum elicits endothelium-dependent relaxation via histamine H1-receptor in rat thoracic aorta. J Ethnopharmacol 2008; 116(2): 223-227.

12. Ale MT, Maruyama $H$, Tamauchi $H$, Mikkelsen $J D$, Meyer AS. Fucose-Containing sulfated polysaccharides from brown seaweeds inhibit proliferation of melanoma cells and induce apoptosis by activation of caspase-3 in vitro. Mar Drugs 2011; 9(12): 2605-2621.

13. Lazebnik YA, Kaufmann SH, Desnoyers S, Poirier G G, Earnshaw WC. Cleavage of poly(ADP-ribose) polymerase by a proteinase with properties like ICE. Nature 1994; 371(6495): 346-347. 